\title{
Investigations on susceptibility of marbled rabbitfish Siganus rivulatus to various infectious marine bacteria
}

\author{
Rabiah Hamze ${ }^{1}$, Nivin Nasser ${ }^{1}$, Mike Osta ${ }^{1}$, Zeina Kassaify ${ }^{2}$, Imad Patrick Saoud ${ }^{1, *}$ \\ ${ }^{1}$ Department of Biology, American University of Beirut, Beirut, Lebanon \\ ${ }^{2}$ Department of Food Science, American University of Beirut, Beirut, Lebanon
}

\section{Email address:}

is08@aub.edu.lb (I. P. Saoud)

\section{To cite this article:}

Rabiah Hamze, Nivin Nasser, Mike Osta, Zeina Kassaify, Imad Patrick Saoud. Investigations on Susceptibility of Marbled Rabbitfish Siganus Rivulatus to Various Infectious Marine Bacteria. Animal and Veterinary Sciences. Vol. 2, No. 6, 2014, pp. 161-168.

doi: $10.11648 /$ j.avs.20140206.11

\begin{abstract}
Disease management in aquaculture is complicated by the fact that various fish species generally vary in their susceptibility to pathogenic microorganisms, thus requiring that every species be studied independently. The present work was performed to investigate the susceptibility of marbled rabbitfish Siganus rivulatus to the potential bacterial pathogens: Aeromonas hydrophila, Mycobacterium marinum, Vibrio anguillarum, Streptococcus iniae, and Yersinia ruckeri. Fish were challenged with the various bacteria and survival and hematological responses were evaluated. Mortalities in all treatments were not significantly greater than the control. However, analyses of hematological parameters suggest that M. marinum is potentially pathogenic to $S$. rivulatus. Additionally, we investigated whether lesions found on wild fish collected from Beirut beach contained any of the five bacterial species of interest. None of these bacteria were present in the lesions, thus suggesting that lesions were caused by other microbes.
\end{abstract}

Keywords: Rabbitfish, Siganus Rivulatus, Disease, Bacteria

\section{Introduction}

In 2010, global aquaculture production was approximately 60 million tons, accounting for nearly half of all fish consumed worldwide [1]. Further growth of the industry will require intensification of culture systems which would potentially increase infectious disease transmission. Such pathogenesis is an outcome of a complex interaction between the fish, the aquatic environment, and disease agents [2]. Accordingly, in order to develop adequate measures to control and prevent diseases, it is necessary to carry out multidisciplinary studies that would identify potential pathogens for each fish host and, subsequently, identify the role of environmental factors affecting disease in order to develop adequate measures to control fish health [3].

Siganids, also called rabbitfish or spinefoot are a family of Indo-Pacific herbivorous marine fishes with good aquaculture potential [4]. Siganus rivulatus are schooling fish that tolerate crowded conditions in captivity [5] and also tolerate broad ranges of temperature [6] and salinity [7]. Siganids, especially Siganus rivulatus, are in demand in the Middle East [8] which makes them economically valuable and interesting to aquaculturists.

Infectious pathogens present in culture systems are usually also present in wild fish populations. However, diseases are more prevalent in culture systems because of stressful conditions such as high stocking density, poor water quality, inadequate nutrition, and injury in the mucosa, scales, or skin of the fish [3]. Moreover, some bacterial strains are primary pathogens that infect fish even with little stress while other opportunistic bacteria infect only heavily stressed fish [9]. Accordingly, understanding a microbe and its pathogenicity towards a fish species facilitates downstream steps that may eventually help in the development of methods to prevent, control, and treat disease.

Bacterial strains that are potentially pathogenic to rabbitfish are poorly studied but we know from anecdotal reports and personal observations that rabbitfish are affected by bacteria and can be treated with antibiotics. Accordingly, we chose to investigate the virulence of five bacterial species known to exist in the Mediterranean Aeromonas hydrophila, Mycobacterium marinum, Vibrio anguillarum, Streptococcus 
iniae and Yersinia ruckeri [3], and to cause disease in marine fish [10].

Aeromonas hydrophila is a Gram-negative bacterium [11] that is an opportunistic pathogen [12]. When pathogenic, A. hydrophila causes a common bacterial disease called motile Aeromonas septicemia [13, 14]. Although A. hydrophila is generally a freshwater fish pathogen, it has been reported to infect marine fish species such as Atlantic salmon and Mediterranean Sea bass [15].

Mycobacterium marinum is a Gram-positive, straight or slightly curved bacillus [16]. M. marinum was found to be pathogenic to fish in an experiment performed on 50 poikilothermic species [17] and has been isolated in 20 marine and fresh water fish species so far [18]. In fish, the bacterium causes mycobacteriosis with symptoms such as emaciation and granulomal lesions and eventually death [19].

Vibrio anguillarum is a Gram-negative, rod-shaped bacterium [20]. Infection with $V$. anguillarum causes vibriosis, a severe condition characterized by deep focal necrotizing myositis, ulcerative necrosis of the body surface and sub-dermal hemorrhages at the base of the fins [21, 22]. The potential capability of $V$. anguillarum to cause huge fish losses in a variety of fish species [23] made it imperative for us to test whether this microorganism is capable of infecting rabbitfish.

Streptococcus iniae is a Gram-positive bacterium [24] that can cause skin lesions and necrotizing myositis upon infection [25]. S. iniae is considered a serious threat to aquaculture and a potential pathogen to rabbitfish.

Yersinia ruckeri is a Gram-negative, rod-shaped bacterium [26] responsible for enteric redmouth (ERM) disease and yersiniosis in salmonids [27]. Infection with Y. ruckeri is characterized by inflammation and redness in the mouth areas and throat [28]. The disease has also been reported in various marine fishes such as eels, sole, sturgeon and turbot [29]. Its pathogenicity in rabbitfish remains to be tested.

In the present work we assessed the virulence of these five piscine pathogenic bacteria to marbled spinefoot and studied the effect of bacterial challenge on hematological parameters. Additionally, we evaluated whether any of the five tested bacterial species existed in lesions in wild fish and hence might be implicated in rabbitfish disease.

\section{Materials and Methods}

\subsection{Fish Acquisition and Holding}

Juvenile marbled spinefoot (S. rivulatus) were caught in traps off the Beirut beach and transported live to the aquaculture research laboratory at the American University of Beirut (AUB). Fish were quarantined in two $1 \mathrm{~m}^{3}$ tanks connected to a biological filter and a sump tank. They were offered a 35\% protein commercial diet (Rangen EXTR 350, Rangen Inc., Buhl, Idaho) ad libitum twice daily. Fish were fasted for 24 hours prior to start of bacterial challenges.

\subsection{Bacterial Cell Culture}

Bacterial strains were obtained from the American Type
Culture Collection (ATCC, Manassas, Virginia, USA). Brain Heart Infusion (BHI) broth and agar were used to grow Vibrio anguillarum (ATCC19264), Streptococcus iniae (ATCC29178T), Yersinia ruckeri (ATCC29473), and Aeromonas hydrophila (ATCC43874). Mycobacterium marinum (ATCC92) was grown in Middlebrook $7 \mathrm{H} 9$ enrichment medium broth and on Middlebrook 7H10 enrichment medium agar. A standard optical density (OD) curve was developed for each bacterial species so that colony forming units (CFU) could be rapidly estimated when challenging the fish.

\subsection{Experiment 1}

Quarantined fish $(8.64 \pm 1.82 \mathrm{~cm} ; 8.57 \pm 3.53 \mathrm{~g}$; mean $\pm \mathrm{SD})$ with no symptoms of disease were randomly distributed into 18 plastic tanks (12 fish per tank) containing $5 \mathrm{~L}$ of filtered seawater and supplied with rigorous aeration. Bacteria were added to each container so that resulting numbers were approximately $10^{7} \mathrm{CFU} / \mathrm{ml}$ and fish challenged for $60 \mathrm{~min}$ as described by [30] Crumlish et al. (2010). The virulence of each bacterial strain to the fish was tested in triplicate. Three tanks served as a control group where broth without bacteria was added. After exposure, fish were rinsed and placed in $52 \mathrm{~L}$ glass recovery tanks filled with filtered, chlorinated then de-chlorinated seawater for 10 days and counted twice daily. Twenty percent of the water in the tanks was changed daily and parameters were maintained at $37 \mathrm{ppt}$ salinity, $25{ }^{\circ} \mathrm{C}$ and pH 8 and feed offered twice daily. Ten days after the challenge, blood was drawn out of three fish from each tank and hematological parameters assessed. Ammonia nitrogen and nitrite nitrogen were tested every other day and remained below $0.2 \mathrm{mg} / \mathrm{L}$.

\subsection{Experiment 2}

Results of experiment 1 suggested that the bacteria tested were not pathogenic to marbled spinefoot at the concentrations tested. Consequently, an additional challenge was performed to confirm results. A strain of $V$. anguillarum known to be very virulent to trout and carp was obtained from the lab of Dr. Daniel Merrifield from the University of Plymouth. This strain in addition to the $V$. anguillarum used in experiment 1 and previously used strain of M. marinum were grown in broth. The challenge was performed in $500 \mathrm{ml}$ glass beakers in order to challenge the fish with $10^{8} \mathrm{CFU} / \mathrm{ml}$ of the bacteria. Fish were randomly distributed into 36 glass beakers (3 fish per beaker) each containing $250 \mathrm{~mL}$ of filtered seawater and supplied with aeration. Bacteria were added to each container so that resulting numbers were approximately $10^{8} \mathrm{CFU} / \mathrm{ml}$ of each $V$. anguillarum (ATCC19264) and $M$. marinum (ATCC927) and the new strain of $V$. anguillarum. The virulence of each of the bacterial strains to the fish was tested in 9 beakers. After exposure, fish from three beakers were pooled, rinsed, and placed in $52 \mathrm{~L}$ glass recovery tanks so that 9 fish were present in each tank with three replicate tanks per treatment. Fish were maintained in the tanks for 10 days and counted twice daily. Twenty percent of the water in the tanks was changed daily and parameters were maintained as in 
experiment 1 .

\subsection{Hematological Parameters}

At the end of experiment 1, blood was taken from three fish per tank by cardiac puncture using heparinized syringes and was placed directly in heparinized tubes. Total red and white blood cells were stained with Natt-Herrick's solution [31] and counts were performed using a modified Neubauer hemocytometer. Slides for differential white blood cell counts were prepared by smearing a drop of fish blood on methanol-wiped microscope slides and stained with Wright-Giemsa stain. Eight hundred WBC were counted on each slide and cell counts were reported as percentage of total WBC count [32].

\subsection{Identifying Bacteria in Fish Lesions}

Sixty three wild adult marbled spinefoot were collected at the Ain El Mreisseh fishing harbor in Beirut. Four fish with lesions were found and their lesions swabbed: A lesion on tail with white spots, a lesion on upper lip, a caudal lesion with tail completely gone, and an abdominal lesion. Swabs were cultured in BHI broth and Middlebrook broth at three temperatures, $25{ }^{\circ} \mathrm{C}, 30{ }^{\circ} \mathrm{C}$ and $37{ }^{\circ} \mathrm{C}$, and resulting isolates were stored in glycerol. BHI bacterial culture grown at $25^{\circ} \mathrm{C}$ allowed for growth of $Y$. ruckeri and $V$. anguillarum present in the lesions. BHI bacterial culture grown at $37^{\circ} \mathrm{C}$ allowed for growth of $A$. hydrophila and S. iniae. Middlebrook bacterial culture at $30{ }^{\circ} \mathrm{C}$ allowed for growth of $M$. marinum present in

the lesions. The various cultures were pelleted and DNA was extracted from the pellets followed by PCR amplification of species-specific genes such as $\mathrm{N}$-acetylmuramoyl-L-alanine amidase [33], lctO [34], hsp 65 [35] for $V$. anguillarum, $S$. iniae, and $M$. marinum respectively. The PCR cycling parameters were: denaturation step of $95^{\circ} \mathrm{C}$ for $3 \mathrm{~min}$, followed by 33 cycles of $30 \mathrm{sec}$ at $95^{\circ} \mathrm{C}, 1 \mathrm{~min}$ of appropriate annealing temperature for each primer pair and $1 \mathrm{~min}$ and 20 sec at $72^{\circ} \mathrm{C}$; then a final elongation step at $72{ }^{\circ} \mathrm{C}$ for $10 \mathrm{~min}$. The band products of the lesions were compared to the band products of pure bacterial cultures of each of the five pathogenic bacteria being evaluated $A$. hydrophila (685bp), $Y$. ruckeri (589bp), V. anguillarum (429bp), S. iniae (870bp), and M. marinum (796bp) to identify whether the causative agent for disease was any of the five bacterial strains.

\subsection{Statistical Analysis}

Data was analyzed using SPSS statistical package (V.18 for Windows, SPSS Inc., Chicago, IL, USA) and reported as mean \pm standard deviation (SD) of the mean. Differences among survival means and hematological parameters were analyzed by one-way ANOVA, followed by Student Newman-Keuls means separation test. Differences were considered significant when $\mathrm{P}<0.05$.

\section{Results}

\subsection{Fish Survival}

Table 1. Fish survival 10 days after challenging S. rivulatus by adding the bacteria at a concentration of $107 \mathrm{CFU} / \mathrm{ml}$ to the culture water for one hour.

\begin{tabular}{|c|c|c|c|}
\hline Bacterial Treatment & Number of dead fish/78 & \% Mortality & $\%$ Survival \\
\hline Control & 1 & 1.2 & 98.8 \\
\hline A. hydrophila & 5 & 6.4 & 93.6 \\
\hline V. anguillarum & 4 & 5.1 & 94.9 \\
\hline Y. ruckeri & 2 & 2.5 & 97.5 \\
\hline S. iniae & 3 & 3.8 & 96.2 \\
\hline M. marinum & 0 & 0 & 100 \\
\hline
\end{tabular}

Table 2. PCR primers used for each specific species, their sequences, target genes, annealing temperatures, and amplicon size.

\begin{tabular}{|c|c|c|c|c|}
\hline Species & Primers & Primer sequence & Annealing temperature $\left({ }^{\circ} \mathrm{C}\right)$ & Amplicon size \\
\hline \multirow{2}{*}{ A. hydrophila } & AH1 & 5'-GAAAGGTTGATGCCTAATACGTA-3' & \multirow{2}{*}{62} & \multirow{2}{*}{$685 \mathrm{bp}$} \\
\hline & $\mathrm{AH} 2$ & 5'-CGTGCTGGCAACAAAGGACAG-3' & & \\
\hline \multirow{2}{*}{ Y. ruckeri } & YerF & 5'-GCGAGGAGGAAGGGTTAAGTG-3' & \multirow{2}{*}{62} & \multirow{2}{*}{589 bp } \\
\hline & YerR & 5'-GAAGGCACCAAGGCATCTCTG-3' & & \\
\hline \multirow{2}{*}{ V. anguillarum } & van-ami8 & 5'-ACATCATCCATTTGTTAC-3' & \multirow{2}{*}{56} & \multirow{2}{*}{$429 \mathrm{bp}$} \\
\hline & van-ami417 & 5'-ССТТАТСАСТАТССАAАTTG-3' & & \\
\hline S. iniae & LOX-2 & 5'-ATATCTGATTGGGCCGTCTAA-3' & 57 & $870 \mathrm{bp}$ \\
\hline \multirow{2}{*}{ M. marinum } & $\mathrm{HS} 12 \mathrm{~F}$ & 5'-AGGGTATGCGGTTCGACAAG-3' & \multirow{2}{*}{52} & \multirow{2}{*}{$796 \mathrm{bp}$} \\
\hline & M2 & 5'-TTGAAGGCGATCTGCTT-3' & & \\
\hline
\end{tabular}

In the first challenge experiment, there were no differences in survival among treatments (Table 1). Control tanks had $98.8 \%$ survival. Fish challenged with $A$. hydrophila had 93.6\% survival and two fish exhibited some bloating and lethargy. Fish challenged with $V$. anguillarum had $94.9 \%$ survival and two of the fish developed lesions suggestive of possible infection. Fish challenged with $S$. iniae had $96.2 \%$ survival and the only symptoms of disease observed were a 
lesion in one fish and lethargy in a few fish during the first four days post challenge. Fish challenged with Y. ruckeri had $97.5 \%$ survival. Fish challenged with $M$. marinum showed no symptoms of disease and had $100 \%$ survival. It is noteworthy that most fish that suffered from lethargy did not die but rather regained vigor by the end of the first week. The little mortality observed happened on days 3,4 , and 5 post challenge. After day 5 , no mortalities were observed in any of the treatments.

In the second experiment as well there were no significant differences in survival among treatments. Fish challenged with the same $V$. anguillarum strain as that used in the first experiment had $89 \%$ survival. Fish treated with the second $V$. anguillarum strain had $99.6 \%$ survival. None of the fish challenged with M. marinum died (Table 2).

\subsection{Hematological Parameters}

Total RBC counts were not significantly different between any of the treatments and the control but the greatest RBC count found in fish challenged with $\mathrm{M}$. marinum, and the least $\mathrm{RBC}$ count found in fish treated with $\mathrm{S}$. iniae, were significantly different from each other (Table 2 and 3). Total WBC counts were not significantly different among fish in the various treatments or between treatments and the control

(Table 2 and 3). However, neutrophil counts were significantly greater in fish treated with $\mathrm{M}$. marinum than the control and all other treatments (Table 3 and 4). No significant difference in monocyte counts was found between treatments and the control. However, fish challenged with M. marinum had significantly fewer monocytes than fish challenged with $\mathrm{A}$ hydrophila, Y. ruckeri, and S. iniae. No significant difference was found in the number of eosinophils among all treatments (Table 3 and 4).

Table 3. Hematological parameters of rabbitfish Siganus rivulatus on day 10 post-challenge with five bacterial strains. Values with common superscript are not significantly different from each other. PSE = Pooled Standard Error

\begin{tabular}{|c|c|c|c|c|c|c|c|c|}
\hline & Parameter & $\begin{array}{l}\text { Total RBC } \\
\left(\times 10^{6} \text { cells } / \mu \mathrm{L}\right)\end{array}$ & WBC (cells $\left./ \mathbf{m m}^{3}\right)$ & $\begin{array}{l}\text { Thrombocyte } \\
(\%)\end{array}$ & $\begin{array}{l}\text { Lymphocyte } \\
(\%)\end{array}$ & $\begin{array}{l}\text { Monocyte } \\
\text { (\%) }\end{array}$ & $\begin{array}{l}\text { Neutrophil } \\
(\%)\end{array}$ & $\begin{array}{l}\text { Eosinophil } \\
(\%)\end{array}$ \\
\hline \multirow{2}{*}{ Control } & Mean \pm SD & $2.98 \pm 0.57^{\mathrm{ab}}$ & $10941.67 \pm 3235.87^{\mathrm{a}}$ & $86.4 \pm 1.47^{\mathrm{a}}$ & $10.6 \pm 3.02^{\mathrm{a}}$ & $0.69 \pm 0.61^{\mathrm{ab}}$ & $2.71 \pm 1.83^{\mathrm{b}}$ & $0.05 \pm 0.09^{\mathrm{a}}$ \\
\hline & Range & $2.04-4.17$ & $7375-17825$ & $73-96$ & $4-15$ & $0-2$ & $0-7$ & 0 \\
\hline \multirow{2}{*}{ A. hydrophila } & Mean \pm SD & $2.87 \pm 0.61^{\mathrm{ab}}$ & $14645.83 \pm 4247.39^{\mathrm{a}}$ & $84.983 \pm 2.08^{\mathrm{a}}$ & $8.94 \pm 1.32^{\mathrm{a}}$ & $1.52 \pm 0.80^{\mathrm{a}}$ & $3.36 \pm 1.13^{\mathrm{b}}$ & $0.15 \pm 0.12^{\mathrm{a}}$ \\
\hline & Range & $2.06-3.43$ & $10950-22475$ & $76-90$ & $7-11$ & $1-2$ & $2-5$ & 0 \\
\hline \multirow{2}{*}{ V. anguillarum } & Mean \pm SD & $3.04 \pm 0.39^{\mathrm{ab}}$ & $12779.17 \pm 3048.25^{\mathrm{a}}$ & $88.9 \pm 2.08^{\mathrm{a}}$ & $7.8 \pm 3.4^{\mathrm{a}}$ & $0.76 \pm 0.43^{\mathrm{ab}}$ & $3.27 \pm 1.47^{\mathrm{b}}$ & $0.07 \pm 0.10^{\mathrm{a}}$ \\
\hline & Range & $2.38-3.46$ & $7525-15900$ & $84-94$ & $4-13$ & $0-1$ & $2-5$ & 0 \\
\hline \multirow{2}{*}{ Y. ruckeri } & Mean \pm SD & $2.78 \pm 0.51^{\mathrm{ab}}$ & $13212.50 \pm 5026.03^{\mathrm{a}}$ & $89.483 \pm 2.08^{\mathrm{a}}$ & $7.96 \pm 3.65^{\mathrm{a}}$ & $1.40 \pm 0.47^{\mathrm{a}}$ & $2.80 \pm 0.70^{\mathrm{b}}$ & $0.15 \pm 0.2^{\mathrm{a}}$ \\
\hline & Range & $2.02-3.62$ & $9450-22250$ & $85-94$ & $4-12$ & $1-2$ & $2-4$ & 0 \\
\hline \multirow{2}{*}{ S. iniae } & Mean \pm SD & $2.56 \pm 0.40^{\mathrm{b}}$ & $11795.83 \pm 4050.17^{\mathrm{a}}$ & $87.467 \pm 2.08^{\mathrm{a}}$ & $8.75 \pm 3.21^{\mathrm{a}}$ & $1.4 \pm 0.28^{\mathrm{a}}$ & $2.92 \pm 1.07^{\mathrm{b}}$ & $0.12 \pm 0.11^{\mathrm{a}}$ \\
\hline & Range & $2.03-3.07$ & $7075-19275$ & $83-92$ & $5-14$ & $1-2$ & $1-4$ & 0 \\
\hline \multirow{2}{*}{ M. marinum } & Mean \pm SD & $3.47 \pm 0.60^{\mathrm{a}}$ & $11004.17 \pm 1240.20^{\mathrm{a}}$ & $89.35 \pm 2.08^{\mathrm{a}}$ & $8.45 \pm 3.19^{\mathrm{a}}$ & $0.35 \pm 0.45^{\mathrm{b}}$ & $12.50 \pm 10.01^{\mathrm{a}}$ & $0^{\mathrm{a}}$ \\
\hline & Range & $2.86-4.43$ & $8975-12550$ & $81-94$ & $5-13$ & $0-1$ & $0-22$ & 0 \\
\hline PSE & & 215926.8 & 1471.7 & 2.084 & 1.257 & 0.222 & 1.519 & 0.047 \\
\hline
\end{tabular}

Table 4. Absolute values for the differential WBC and thrombocyte counts for 42 rabbitfish S. rivulatus (6 of each treatment and 12 from controls) on day 10 post-challenge with five bacterial strains.

\begin{tabular}{|c|c|c|c|c|c|c|c|}
\hline & Parameter & $\begin{array}{l}\text { Thrombocyte } \\
\left(\text { cells } / \mathbf{m m}^{3}\right)\end{array}$ & $\begin{array}{l}\text { Lymphocyte } \\
\left(\text { cells } / \mathbf{m m}^{3}\right)\end{array}$ & $\begin{array}{l}\text { Neutrophil } \\
\left(\text { cells } / \mathbf{m m}^{3}\right)\end{array}$ & $\begin{array}{l}\text { Monocyte } \\
\left(\text { cells } / \mathbf{m m}^{3}\right)\end{array}$ & $\begin{array}{l}\text { Eosinophil } \\
\left(\text { cells } / \mathbf{m m}^{3}\right)\end{array}$ & $\mathbf{N} / \mathbf{L}^{*}$ \\
\hline \multirow[t]{2}{*}{ Control } & Mean $\pm \mathrm{SD}$ & $9388.1 \pm 2569.9$ & $1168.3 \pm 382.27$ & $249.84 \pm 135.33$ & $50.27 \pm 50.37$ & $4.79 \pm 8.4$ & $0.34 \pm 0.49$ \\
\hline & Range & $6097-14678$ & $383-1664$ & $76-555$ & $27-145$ & $0-22$ & $0.07-1.45$ \\
\hline \multirow[t]{2}{*}{ A. Hydrophila } & Mean \pm SD & $10075.13 \pm 3817.73$ & $923.63 \pm 242.62$ & $408.71 \pm 247.34$ & $163.2 \pm 62.84$ & $14.67 \pm 14.85$ & $0.36 \pm 0.17$ \\
\hline & Range & $6085-17380$ & $613-1290$ & $212-803$ & $96-256$ & $0-40$ & $0.18-0.58$ \\
\hline \multirow[t]{2}{*}{ V. anguillarum } & Mean \pm SD & $11780.97 \pm 4696.09$ & $999.24 \pm 454.32$ & $407.55 \pm 160.81$ & $101.23 \pm 62$ & $5.31 \pm 8.23$ & $0.53 \pm 0.38$ \\
\hline & Range & $8537-20433$ & $410-1622$ & $242-611$ & $18-185$ & $0-16$ & $0.18-1.15$ \\
\hline \multirow[t]{2}{*}{ Y. ruckeri } & Mean \pm SD & $11397.33 \pm 2589.65$ & $1058.78 \pm 619.32$ & $354.19 \pm 118.63$ & $177.45 \pm 83.49$ & $21.14 \pm 30.9$ & $0.4 \pm 0.19$ \\
\hline & Range & $6860-14178$ & $401-1890$ & $247-551$ & $125-345$ & $0-80$ & $0.17-0.66$ \\
\hline \multirow[t]{2}{*}{ S. iniae } & Mean \pm SD & $12876.98 \pm 4118.19$ & $1237.38 \pm 433.94$ & $387.73 \pm 193.97$ & $208.24 \pm 91.59$ & $13.48 \pm 12.6$ & $0.38 \pm 0.26$ \\
\hline & Range & $9581-20602$ & $858-1987$ & $234-700$ & $121-375$ & $0-27$ & $0.12-0.79$ \\
\hline \multirow[t]{2}{*}{ M. marinum } & Mean \pm SD & $9811.49 \pm 1001.02$ & $947.63 \pm 430.73$ & $1302.44 \pm 978.41$ & $36.22 \pm 44.85$ & $0 \pm 0$ & $2.02 \pm 2$ \\
\hline & Range & $8167-11010$ & $464-1715$ & $313-2295$ & $0-104$ & $0-0$ & $0.29-4.26$ \\
\hline
\end{tabular}

*N/L: Neutrophil to lymphocyte ratio 


\subsection{Testing Lesions for Presence of Bacteria}

Species-specific amplicons were detected from DNA extracted from pure bacterial cultures. However, none of these amplicons were detected in cultures originating from the fish lesions, irrespective of the growth temperature (Figure 1).

The five bacteria tested were not associated with the lesions on the fish.

\section{Discussion}

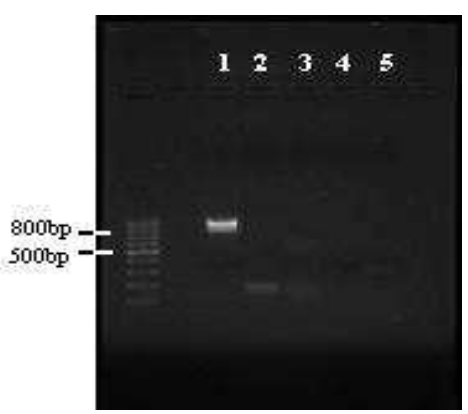

Figure 1. Agarose Gel Electrophoresis for PCR results for Middlebrook bacterial culture for all fish; Fish 1 (Column 2); fish 2 (Column 3); fish 3 (Column 4); fish 4 (Column 5) grown at $30^{\circ} \mathrm{C}$ show no presence of $M$. marinum DNA when compared to pure M. marinum DNA (Column 1).

The present work was performed to assess the susceptibility of the marbled spinefoot Siganus rivulatus to five known piscine pathogenic bacterial species. Results suggest that the marbled spinefoot is quite resistant to the bacterial strains used when challenged by adding the pathogens to the culture water. Fish in the present work were challenged with bacteria in the water because that is more relevant to aquaculturists. However experiments have shown that siganids could be susceptible to bacterial infections when injected with the pathogen [36]. The reader should also keep in mind that information on bacterial diseases in rabbitfish is very limited and thus our discussion is limited to the present work with little to compare to.

Among fish exposed to A. hydrophila, one had a bloated stomach and died on day 3 post infection and another was lethargic until day five but recovered. The bloated stomach could be a sign of $A$. hydrophila infection but could also be the result of getting stung by another fish's spine during handling. Effects observed were not similar to those reported in the literature. The remaining fish in the $A$. hydrophila treatment appeared healthy and did not exhibit any signs of infection. When European eels Anguilla anguilla were challenged with A. hydrophila, a $17-34 \%$ mortality was observed along with symptoms of tail ulcerations and purulent liquid in the gills [37]. Whilst present results suggest that Siganus rivulatus are quite resistant to $A$. hydrophila, one should remember that $A$. hydrophila is an opportunistic pathogen and a lack of infection of fish could be because the fish used were healthy and in good physiological condition.

The Vibrio anguillarum challenge resulted in an average mortality of $5 \%$. Only one fish showed signs of disease and lethargy before dying; all other fish seemed healthy. In a similar immersion challenge, visible external signs of vibriosis on coho salmon Oncorhynchus kisutch caused by $V$. anguillarum were reported [38]. A study found that rainbow trout Salmo gairdneri and saithe Pollachim virem were susceptible to $V$. anguillarum isolated from conspecifics but that the bacteria were less pathogenic or non-pathogenic to fish species they were not isolated from [39]. Thus, the virulence of $V$. anguillarum is probably species-specific and a strain infectious to one species of fish might have no pathogenicity in another. In the present work, S. rivulatus appeared not to be affected by $V$. anguillarum.

In the Yersinia ruckeri challenge, only $2 \%$ of the fish died compared to $1 \%$ mortality in the control treatment; none showed any inflammation or redness in the mouth areas and throat, as expected from yersiniosis (red mouth disease). When challenged with Y. ruckeri under normal conditions, rainbow trout Oncorhynchus mykiss had $16.7 \%$ mortality [40] and Atlantic salmon showed $83 \%$ mortality and showed obvious yersiniosis [41]. Healthy marbled spinefoot appear to be resistant to $Y$. ruckeri.

Fish treated with $S$. iniae didn't develop any skin lesions which tend to be the typical sign of streptococcal infection. Although some fish were lethargic for a few days following the challenge, results are not significant because lethargy was observed in the other four treatments and the control. All fish regained energy and became active a couple of days following the challenge. In similar experiments using fish susceptible to $S$. iniae, such as sunshine bass, barramundi Lates calcarifer, and Japanese flounder Paralichthys olivaceus, excessive mortality was observed [42-44]. Streptococcus iniae was also found to be very pathogenic to the rabbitfish Siganus canaliculatus [45]. However, no mortality was seen when channel catfish Ictalurus punctatus were challenged with the bacterium [46]. Apparently, S. iniae does not affect all species similarly. Additionally, stress also appears to affect fish resistance to the bacterium. When non-stressed blue tilapia Tilapia aurea were challenged with $S$. iniae, no signs of disease were observed [47]. However, when the same fish were stressed by scraping off some scales then challenged with the bacteria, mortality increased to $90 \%$. Accordingly, although fish in the present work were not affected by S. iniae, they may be susceptible if stressed.

Fish treated with Mycobacterium marinum had no mortality and didn't show any signs of Mycobacterium infection such as emaciation or lesions. When zebra fish, a model for $M$. marinum pathology was challenged with $M$. marinum, $10 \%$ of the fish died [48]. Survival results thus suggest that marbled rabbitfish are not susceptible to $M$. marinum. The second challenge with $M$. marinum and two $V$. anguillarum strains further confirmed this finding. It appears that even in stressful conditions and a greater concentration of bacteria, $S$. rivulatus is resistant to short term challenges with M. marinum and $V$. anguillarum.

RBC count was less in fish challenged with $S$. iniae than in control or any of the other treatments and greatest in fish challenged with $M$. marinum. Similar results were observed in 
Coho salmon Oncorhynchus kisutch and in rainbow trout Oncorhynchus mykiss upon infection with Vibrio anguillarum $[38,49]$. However, stressful conditions have also been shown to cause a significant increase in RBC counts [50]. Accordingly, we suspect that $M$. marinum challenge must have been stressful to $S$. rivulatus but the fish were able to fight off any infection in the ten days post challenge which are reflected in the increase rather than decrease in RBC counts. This analysis is supported by observations of neutrophil counts discussed below.

Upon infection, WBC counts of fish tend to increase $[38,51$, 52]. Although WBC counts in the present work were not significantly different among treatments, the challenged fish had slightly greater counts than control fish. These results suggest that fish might have reacted to the challenges but because blood parameters were investigated ten days post challenge, any possible infection was already dealt with. Perhaps, had it been possible to measure hematological parameters only a couple of days post challenge, we would have observed an effect of bacterial challenge on WBC counts.

Differential thrombocyte and lymphocyte counts in our study did not reveal differences amongst treatments. In pacu Piaractus mesopotamicus challenged with A. hydrophila and rainbow trout infected with $V$. anguillarum the number of thrombocytes and lymphocytes in blood decreased 24 hours post-challenge $[53,54]$, suggesting migration of lymphocytes and thrombocytes to inflammation site and their role as defense cells at the onset of infection. Our experimental protocol did not allow us to test whether lymphocytes and thrombocytes were involved in helping S. rivulatus stave off infection. Because we measured these parameters on day 10 post-infection, we may have allowed thrombocytes and lymphocytes to return to their original quantities in the bloodstream even if they had decreased post challenge.

Blood of fish challenged with Mycobacterium marinum had significantly more neutrophils and significantly less monocytes compared to the control and other treatments. Previous work had reported increases in neutrophils and monocytes following bacterial infection [53-55] but we found no reports of increase in neutrophils and decrease in monocytes. Neutrophils and macrophages, which are the first responders to infection and develop from the same myeloid precursor stem cells as monocytes, kill microbes and bacteria through phagocytosis and are important components of the innate immune system [56]. An acute inflammatory response would be characterized by high numbers of neutrophils in blood and accumulation of neutrophils and macrophages at the site of injury or infection $[57,58]$. Accordingly, it is possible that in the present experiment $M$. marinum affected the fish causing an increase in macrophages at the expense of monocytes that would originate from the same stem cells.

Bacterial DNA obtained from lesions on wild fish did not match any of the five known pathogens tested in the present work. No extra work was done on the samples because it is difficult to come to any conclusions on fish disease from these lesions. The history of the fishes was not known and the lesions were found on only a few individuals in the wild population and on differing body parts. We know from experience that marbled spinefoot are susceptible to bacterial problems that can be treated with Florfenicol. We also know that stressed fish are very susceptible to disease. However, $S$. rivulatus is very tolerant of crowded conditions [5] and intensive farming does not cause stress. Anecdotal observations in our laboratory suggest that when exposed to low oxygen or high temperatures, the fish get diseased and die within a few days. Future work will investigate whether bacteria used in the present work become pathogenic when fish are stressed before or during challenge. The fact remains that non-stressed rabbitfish are quite resistant to common pathogenic bacteria, and are thus a good candidate for commercial aquaculture.

\section{Acknowledgements}

The present work was funded partially by a grant from the Lebanese Council for Scientific Research and partially by the University Research board of the American university of Beirut.

\section{References}

[1] World aquaculture 2010, FAO Fisheries and Aquaculture Department. Technical

Paper. No. 500/1. Rome, FAO. 2011. 105 pp.

[2] Snieszko, S.F.1975. History and present status of fish diseases. J. Wildl. Dis., 11, 446-459.

[3] Toranzo, A.E., Magariños, B. and Romalde, J.L. 2005. A review of the main bacterial fish diseases in mariculture systems. Aquaculture, 246, 37-61.

[4] Ghanawi, J., Saoud, I.P. and Shalaby, S.M. 2010. Effect of size sorting on growth performance of juvenile spinefoot rabbitfish, Siganus rivulatus. Journal of the World Aquaculture Society, 41, 565-573.

[5] Saoud, I.P., Ghanawi, J. and Lebbos, N. 2008. Effects of stocking density on the survival, growth, size variation and condition index of juvenile rabbitfish Siganus rivulatus. Aquaculture International, 16, 109-116.

[6] Saoud, I.P., Mohanna, C. and Ghanawi, J. 2008. Effects of temperature on survival and growth of juvenile spinefoot rabbitfish (Siganus rivulatus). Aquaculture Research, 39, 491-497.

[7] Saoud, I.P., Kreydiyyeh, S., Chalfoun, A. and Fakih, M. 2007. Influence of salinity on survival, growth, plasma osmolality and gill $\mathrm{Na}^{+} / \mathrm{K}^{+}$-ATPase activity in the rabbitfish Siganus rivulatus. Journal of Experimental Marine Biology and Ecology, 348, 183-190.

[8] Deniz, H. 2000. Marine aquaculture in Turkey and potential finfish species. Recent advances in Mediterranean aquaculture finfish species diversification. Zaragoza: CIHEAM, pp: 349-358. (Cahiers Options Méditerranéennes; n. 47). 
[9] Harikrishnan, R. and Balasundaram, C. 2005. Modern trends in Aeromonas hydrophila disease management with fish. Reviews in Fisheries Science, 13, 281-320.

[10] Pridgeon, J.W. and Klesius, P.H. 2012. Major bacterial diseases in aquaculture and their vaccine development. Animal Science Reviews, 141-156.

[11] Shotts, E.B., Jr., Gaines, J.L., Jr., Martin, L. and Prestwood, A.K. 1972. Aeromonas-induced deaths among fish and reptiles in an eutrophic inland lake. J Am Vet Med Assoc, 161, 603-607.

[12] Plumb, J.A., Grizzle, J.M. and Defigueiredo, J. 1976. Necrosis and bacterial infection in channel catfish (Ictalurus punctatus) following hypoxia. J Wildl Dis, 12, 247-253.

[13] Bullock, G.L. and Snieszko, S.F. 1969. Bacteria in blood and kidney of apparently healthy hatchery trout. Transactions of the American Fisheries Society, 98, 268-271.

[14] Johnson, S.K. and Williams, E. 1972. Bacteriological survey of freshwater fishes of the Tensaw River, Alabama. J. Ala. Acad. Sci, 43, 19-22.

[15] Doukas, V., Athanassopoulou, F., Karagouni, E. and Dotsika, E. 1998. Aeromonas hydrophila infection in cultured sea bass, Dicentrarchus labrax L., and Puntazzo puntazzo Cuvier from the Aegean Sea. J Fish Dis, 21, 317-320.

[16] Parent, L.J., Salam, M.M., Appelbaum, P.C. and Dossett, J.H. 1995. Disseminated Mycobacterium marinum infection and bacteremia in a child with severe combined immunodeficiency. Clin Infect Dis, 21, 1325-1327.

[17] Clark, H.F. and Shepard, C.C. 1963. Effect of environmental temperatures on infection with Mycobacterium marinum (balnei) of mice and a number of poikilothermic species. J Bacteriol, 86, 1057-1069.

[18] Ucko, M. and Colorni, A. 2005. Mycobacterium marinum infections in fish and humans in Israel. J Clin Microbiol, 43, 892-895.

[19] Van Duijn Jnr, C. 1981. Tuberculosis in fishes. Journal of Small Animal Practice, 22, 391-411.

[20] Myhr, E., Larsen, J.L., Lillehaug, A., Gudding, R., Heum, M. and Håstein, T. 1991. Characterization of Vibrio anguillarum and closely related species isolated from farmed fish in Norway. Appl Environ Microbiol, 57, 2750-2757.

[21] Haastein, T. and Holt, G. 1972. The occurrence of vibrio disease in wild Norwegian fish. Journal of Fish Biology, 4, 33-37.

[22] Munn, C.B. 1977. Vibriosis in fish and its control. Aquaculture Research, 8, 11-15.

[23] Toranzo, A.E., Santos, Y., Lemos, M.L., Ledo, A. and Bolinches, J. 1987. Homology of Vibrio anguillarum strains causing epizootics in turbot, salmon and trout reared on the Atlantic coast of Spain. Aquaculture, 67, 41-52.

[24] Stoffregen, D.A., Backman, S.C., Perham, R.E., Bowser, P.R. and Babish, J.G. 1996. Initial disease report of Streptococcus iniae infection in hybrid striped (sunshine) bass and successful therapeutic intervention with the fluoroquinolone antibacterial enrofloxacin. Journal of the World Aquaculture Society, 27, 420-434.

[25] Bercovier, H., Ghittino, C. and Eldar, A. 1997. Immunization with bacterial antigens: infections with streptococci and related organisms. Dev Biol Stand, 90, 153-160.

[26] Ross, A.J., Rucker, R.R. and Ewing, W.H. 1966. Description of a bacterium associated with redmouth disease of rainbow trout (Salmo gairdneri). Can J Microbiol, 12, 763-770.

[27] Fernández, L., Méndez, J. and Guijarro, J.A. 2007. Molecular virulence mechanisms of the fish pathogen Yersinia ruckeri. Vet Microbiol, 125, 1-10.

[28] Ewing, W., Ross, A., Brenner, D.J. and Fanning, G. 1978. Yersinia ruckeri sp. nov., the Redmouth (RM) Bacterium. International Journal of Systematic Bacteriology, 28, 37-44.

[29] Carson, J. and Wilson, T. 2009. Yersiniosis in fish. Australia and New Zealand Standard Diagnostic Procedure, 1-19.

[30] Crumlish, M., Thanh, P.C., Koesling, J., Tung, V.T. and Gravningen, K. 2010. Experimental challenge studies in Vietnamese catfish, Pangasianodon hypophthalmus (Sauvage), exposed to Edwardsiella ictaluri and Aeromonas hydrophila. Journal of Fish Diseases, 33(9), 717-722.

[31] Natt, M.P. and Herrick, C.A. 1952. A new blood diluent for counting the erythrocytes and leucocytes of the chicken. Poultry Science, 31, 735-738.

[32] Klontz, G. 1994. Fish hematology. Techniques in fish immunology, 3, 121-131.

[33] Hong, G.E., Kim, D.G., Bae, J.Y., Ahn, S.H., Bai, S.C. and Kong, I.S. 2007. Species-specific PCR detection of the fish pathogen, Vibrio anguillarum, using the amiB gene, which encodes N-acetylmuramoyl-L-alanine amidase. FEMS Microbiol Lett, 269, 201-206.

[34] Mata, A.I., Blanco, M.M., Dominguez, L., Fernandez-Garayzabal, J.F. and Gibello, A. 2004. Development of a PCR assay for Streptococcus iniae based on the lactate oxidase (lctO) gene with potential diagnostic value. Vet Microbiol, 101, 109-116.

[35] Ucko, M., Colorni, A., Kvitt, H., Diamant, A., Zlotkin, A. and Knibb, W.R. 2002. Strain variation in Mycobacterium marinum fish isolates. Appl Environ Microbiol, 68, 5281-5287.

[36] Saeed, M., Alamoudi, M. and Al Harbi, A. 1990. Histopathology of Pseudomonas putrefaciens associated with disease in cultured rabbitfish, Siganus rivulatus (Forskal). J Fish Dis, 13, 417-422.

[37] Esteve, C., Biosca, E.G. and Amaro, C. 1993. Virulence of Aeromonas hydrophila and some other bacteria isolated from European eels Anguilla anguilla reared in fresh water. Dis Aquat Organ, 16, 15-20.

[38] Harbell, S.C., Hodgins, H.O. and Schiewe, M.H. 1979. Studies on the pathogenesis of vibriosis in coho salmon Oncorhynchus kisutch (Walbaum). J Fish Dis, 2, 391-404.

[39] Egidius, E.C. and Andersen, K. 1978. Host-specific pathogenicity of strains of Vibrio anguillarum isolated from rainbow trout Salmo gairdneri Richardson and saithe Pollachius virens (L.). J Fish Dis, 1, 45-50.

[40] Skov, J., Kania, P.W., Holten-Andersen, L., Fouz, B. and Buchmann, K. 2012 Immunomodulatory effects of dietary beta-1,3-glucan from Euglena gracilis in rainbow trout (Oncorhynchus mykiss) immersion vaccinated against Yersinia ruckeri. Fish Shellfish Immunol, 33, 111-120. 
[41] Bridle, A.R., Koop, B.F. and Nowak, B.F. 2012. Identification of surrogates of protection against yersiniosis in immersion vaccinated Atlantic salmon. PLoS One, 7, e40841.

[42] Nguyen, H.T., Kanai, K. and Yoshikoshi, K. 2001. Immunohistochemical examination of experimental Streptococcus iniae infection in Japanese flounder Paralichthys olivaceus. The Japanese Society of Fish Pathology, 36, $169-178$.

[43] Bromage, E.S. and Owens, L. 2002. Infection of barramundi Lates calcarifer with Streptococcus iniae: effects of different routes of exposure. Dis Aquat Organ, 52, 199-205.

[44] Darwish, A.M. 2007. Laboratory efficacy of florfenicol against Streptococcus iniae infection in sunshine bass. J Aquat Anim Health, 19, 1-7.

[45] Yuasa, K., Kitancharoen, N., Kataoka, Y. and Al-Murbaty, F.A. 1999. Streptococcus iniae, the causative agent of mass mortality in rabbitfish Siganus canaliculatus in Bahrain. J Aquat Anim Health, 11, 87-93.

[46] Evans, J.J., Klesius, P.H., Pasnik, D.J. and Shoemaker, C.A. 2007. Influence of natural Trichodina sp. parasitism on experimental Streptococcus iniae or Streptococcus agalactiae infection and survival of young channel catfish Ictalurus punctatus (Rafinesque). Aquaculture Research, 38, 664-667.

[47] Darwish, A.M., Rawles, S.D. and Griffin, B.R. 2002. Laboratory efficacy of Oxytetracycline for the control of Streptococcus iniae infection in Blue tilapia. J Aquat Anim Health, 14, 184-190.

[48] Harriff, M.J., Bermudez, L.E. and Kent, M.L. 2007. Experimental exposure of zebrafish, Danio rerio (Hamilton), to Mycobacterium marinum and Mycobacterium peregrinum reveals the gastrointestinal tract as the primary route of infection: a potential model for environmental mycobacterial infection. J Fish Dis, 30, 587-600.

[49] Řehulka, J. 2002. Aeromonas causes severe skin lesions in rainbow trout (Oncorhynchus mykiss): Clinical pathology, haematology, and biochemistry. Acta Veterinaria Brno, 71, 351-360.
[50] Montero, D., Izquierdo, M.S., Tort, L., Robaina, L. and Vergara, J.M. 1999. High stocking density produces crowding stress altering some physiological and biochemical parameters in gilthead seabream, Sparus aurata, juveniles. Fish Physiology and Biochemistry, 20, 53-60.

[51] Harikrishnan, R., Nisha Rani, M. and Balasundaram, C. 2003. Hematological and biochemical parameters in common carp, Cyprinus carpio, following herbal treatment for Aeromonas hydrophila infection. Aquaculture, 221, 41-50.

[52] Harikrishnan, R., Balasundaram, C. and Heo, M.S. 2010. Herbal supplementation diets on hematology and innate immunity in goldfish against Aeromonas hydrophila. Fish Shellfish Immunol, 28, 354-361.

[53] Lamas, J., Santos, Y., Bruno, D.W., Toranzo, A.E. and Anadón, R. 1994. Non-specific cellular responses of rainbow trout to Vibrio anguillarum and its extracellular products (ECPs). Journal of Fish Biology, 45, 839-854.

[54] Garcia, F., Pilarski, F., Onaka, E.M., De Moraes, F.R. and Martins, M.L. 2007. Hematology of Piaractus mesopotamicus fed diets supplemented with vitamins $\mathrm{C}$ and $\mathrm{E}$, challenged by Aeromonas hydrophila. Aquaculture, 271, 39-46.

[55] Bruno, D.W. and Munro, A.L.S. 1986. Haematological assessment of rainbow trout, Salmo gairdneri Richardson, and Atlantic salmon, Salmo salar L., infected with Renibacterium salmoninarum. J Fish Dis, 9, 195-204.

[56] Ward, P.D., Tatner, M.F., and Horne, M.T. 1985. Factors influencing the efficacy of vaccines against vibriosis caused by Vibrio anguillarum. In: M.J., Manning, M.F., Tatner (eds.). Fish Immunology. Academic Press, London, pp. 221-229.

[57] Baldwin, G.C., Fuller, N.D., Roberts, R.L., Ho, D.D. and Golde, D.W. 1989. Granulocyte- and granulocyte-macrophage colony-stimulating factors enhance neutrophil cytotoxicity toward HIV-infected cells. Blood, 74(5), 1673-1677.

[58] Secombes, C.J. and Fletcher, T.C. 1992. The role of phagocytes in the protective mechanisms of fish. Annual Review of Fish Diseases, 2, 53-71. 